\title{
Ixopo: The evolution of a South African Buddhist centre.
}

\author{
by Michel Clasquin
}

The Buddhist Retreat Centre (BRC), about 12 kilometers from the town of Ixopo in Kwazulu-Natal Province, South Africa, opened its doors for business in 1980. For twenty-five years it has been at the centre of the small but growing South African Buddhist community - to such an extent, indeed, that the name of the town has become transposed onto the centre, and within this community a question such as "Have you been to Ixopo recently?" refers not to the town itself, but to the BRC. This gives us an initial indication of how influential the centre has become.

To mark the BRC's impending 25th anniversary, I researched its history, its functioning within its community and how it is likely to forge ahead. This entailed interviews with the founder and with staff members and teachers past and present, as well as a perusal of brochures and other publications the centre has produced over the years.

\section{Founding and prehistory}

The history of the BRC, especially in its early years, is inextricably intertwined with the personal history of its founder, Louis van Loon, and to understand why the BRC came into being we need to go back far beyond its official opening in 1980.

Van Loon was born to a thoroughly secular family in Amsterdam, the Netherlands in 1935. In 1956 he came to South Africa as a newly-qualified engineer. Apart from his professional qualifications however, like many of his generation, his education had been interrupted by World War II and postwar austerities, and he was very much self-educated.

At the time, the Dutch government was subsidizing the emigration of young, qualified people to various other parts of the world, South Africa included. When a job opportunity in South Africa came up, Van Loon did not hesitate. He arrived in the country with very little English, fifty pounds of subsidy money in hand and two suitcases, one filled with clothes, the other with art materials.

After six months he had taken charge one of his company's sidelines, a soil analysis division, and it was during an investigation for this division that he first came to Durban. He persuaded his company to move the soil division to Durban, arguing that the far more diverse conditions in the area made it a more suitable location than the relatively uniform soil conditions of the Transvaal. Two years later, he started his own professional practice as architect and consulting engineer.

Soon afterwards, Van Loon was sufficiently well established on a professional level to devote time to his philosophical interests. He became involved with Theosophy, "in those days, probably one of the most powerful alternative ways of seeing the world,"1 and then more particularly with the Theosophist offshoot, the Alice Bailey movement. It was in these circles that Van Loon got his first taste of Asian thought: "chakras, and kundalini and world cycles ... all that stuff." By then, he had also become a vegetarian and had taught himself astrology. He was, in fact, fast gaining a reputation for casting accurate horoscopes. Under the direction of $\mathrm{Dr}$ Douglas Baker, an Alice Bailey enthusiast, Van Loon set up a study group in Durban.

\footnotetext{
${ }^{1}$ Interview: L Van Loon
} 
It was while setting up the group's management structure that he first met his future first wife, Molly.

A few years after their marriage, the Van Loons travelled to the East. Molly had been born and raised in colonial Burma, and this was supposed to have been a simple nostalgic trip for her benefit. Instead, they encountered classical Buddhist art in a Bombay museum. The Van Loons became fascinated by Asian art. They started what would later become known as the Molly van Loon collection of Buddhist Art, ${ }^{2}$ now sadly in the process of being dispersed. During this and many subsequent trips to Asia, the Van Loons met with Tibetan lamas, started to learn meditation practice in Sri Lanka, and met some of the prominent people who were travelling in India at the time. Louis started to act as spokesperson for the incipient Buddhist community at conferences in Durban and this led to him giving lectures on Buddhism at the University of Durban-Westville, marking the beginning of Buddhist Studies in South African academia.

In 1969, during one of their journeys in India, Louis van Loon contracted a disease for which Indian doctors had neither diagnosis nor cure. They left for the highlands of Sri Lanka: even if Molly could not nurse him back to health there, at least it would be a more pleasant place to die.

We made it, barely. It was a little hotel and we were the only guests. I dragged myself out of the foyer and promptly collapsed. I was unconscious for three days and two nights, sweating out liters of fluid. And then I woke up, crystal clear, reborn. I was weak, of course. After another day or two I was sufficiently strong to stand on my feet and I went for a walk. [They walked towards a small dam nearby and] standing there, there were all these hills disappearing into the distance, and tea estates and so on. And it was then that I said to myself, 'I must go back to South Africa as soon as possible. And when we are back we must establish Buddhism there. We must get a property somewhat like this, with hills receding into the distance, and build a meditation centre'. ${ }^{3}$

By then, a few meditation centres already existed, mostly in America, but neither of the Van Loons had ever visited one, so they had very little information on what to look for. Eventually they found the farm on which the BRC was to be established and bought it virtually sight unseen.

There was only one corrugated iron shack on the property, in which a Zulu family lived. It would be ten hard years before the farm was ready to accept retreatants. First, the Van Loons started to visit existing meditation centres in the Western world. But all of those consisted of existing buildings that had been converted. Still, it was a useful exercise in this planning stage. Only around 1976 did they actually start building on the farm. During the next four years, Louis and Molly van Loon would come to the farm weekend after weekend, working from dusk till dawn. The concept changed as they went along: What is today the centre's meditation hall was initially designed for triple duty as kitchen and dining hall as well, but then the entire structure became the meditation hall, which today is filled to

\footnotetext{
${ }^{2}$ See Van Loon (1989).

${ }^{3}$ Interview: L Van Loon
} 
capacity almost every weekend. Now that they had a meditation hall that could hold thirty people, they needed to build accommodations for that number. Mervyn Croft and his brother were already active at this stage: As he relates, "During those times [when Louis and Molly had other commitments] we would go out, pay the wages, maybe fix a broken motor ... two weeks later we'd go back and pay the next lot of wages."

The pedestal for the great Buddha statue was built in this period, but the statue itself would have to wait a little longer. The stupa ${ }^{5}$ on the adjoining hill, was equally one of the first structures they planned to build. In 1972, long before there was any official activity on the farm, the appropriate spot was indicated to Louis van Loon by Lama Anagarika Govinda. A foundation stone was immediately laid, and some years later, when the centre was holding its first-ever gardening retreat, an impromptu decision was made to build the stupa, and it was done within three weeks. Only afterwards did they realise that when they started to dig the foundations, it was in fact ten years to the day since the cornerstone had been laid.

By 1980, the centre was thought to be sufficiently developed to hold its first retreats. Building would continue intermittently, however. When one now looks at the tiny rondavel that is the teahouse, it is easy to see why the large studio next to it was the first priority, and it was finished in 1987. Other buildings that have gone up since the official opening have been a residence for the Van Loons, and various types of accommodation for resident staff and visiting teachers. At the moment, however, there seem to be no further plans for expansion, certainly not to increase the 30-odd retreatants the centre can accommodate at any time.

\section{Further development}

In March 1980, then, the BRC opened its doors for its first retreat. Press coverage of the event was quite positive, though it seems to have been largely restricted to the local Kwazulu-Natal Press. ${ }^{6}$

Initially, the Centre's staff consisted of five people: Louis and Molly van Loon, Antony Osler, Clifford Harwood and Sally-Joan Heywood. ${ }^{7}$ Since the Van Loons continued to reside in Durban, there were effectively three people at the centre on a full-time basis. Today, the centre operates with a full-time staff complement of seven people, most of whom stay at the BRC for six months to a year. Positions tend to be spoken for well in advance, with applications coming in even from outside South Africa.

For some time before the official opening, the Van Loons had been searching for a full-time teacher among the monastics they met during their travels, but had not managed to find one with the wide knowledge of different schools of Buddhism that

\footnotetext{
${ }^{4}$ Interview: M Croft.
}

${ }^{5} \mathrm{~A}$ stupa is a peculiarly Indian Buddhist monument that constitutes a solid hemispherical construction on a square base, surmounted by a spire. Stupas contain relics of the Buddha himself or of other significant figures in Buddhist history.

${ }^{6}$ See Fairall (1980), Horning (1980), Natal Witness Reporter (1980), Still (1980).

${ }^{7}$ See Fairall (1980). Harwood would later take semi-monastic vows and be known as Anagarika Kolitha. 
they felt this country required. Louis van Loon and Antony Osler met at a retreat in Cape Town shortly before the official opening and Osler accepted Van Loon's offer to become the BRC's first resident teacher.

The BRC's inaugural newsletter makes for interesting reading; seen in retrospect, it shows both how the $\mathrm{BRC}$ has continued to remain true to its original vision and how it had to adapt to local circumstances and the vicissitudes of personnel changes. Some parts of it, such as the general description of Buddhism, closely resemble phrases encountered in BRC newsletters to this day. But the programme for 1980 was very Zen-oriented, with retreats like "Zen and the Judaeo-Christian experience," "Zen in the art of listening", "Executive Zen" and no less than 11 nine-day sesshins (intensive Japanese-style retreats). ${ }^{8}$ Perhaps this was too ambitious - today the Dharma Centre in Robertson, an explicitly Zen-oriented organisation, only holds about 3-4 nine-day sesshins a year. As we shall see, it took the BRC a few years of experimenting to come up with the right mix of retreat topics.

Clearly, at the outset, Van Loon saw himself primarily as the centre's administrator and organiser, while Osler's role would be that of resident teacher and this can be seen as one reason for the emphasis on Zen in the early years. There is one major exception, however. Throughout the Buddhist world, the main religious festival, Wesak, celebrates the birth, enlightenment and death of the Buddha, all three of which are thought to have taken place on the same day of the year. However, there is no agreement between Buddhist schools about when this was supposed to have taken place; indeed there are even sub-schools that celebrate Wesak on different days. Since its inception, the BRC has celebrated Wesak around the date traditionally held to by the Sri Lankan branch of the Theravada tradition, ${ }^{9}$ rather than several months later when the Japanese Zen tradition celebrates it.

The very first retreat offered by the BRC was almost fully booked: a martial arts group in Durban had heard of the place and was eager to explore the relation between their practice and Zen. It turned out to be a test for the newly-established rules of conduct (which apply to this day): "We had decided that people should be silent in the lodge at night, but all that happened was that they tiptoed up and down visiting each other in their rooms, the guys visiting the girls and so on." 10 The very next retreat, however, saw only a single retreatant.

The 1980 newsletter also envisages renting out the BRC as a conference venue to like-minded organisations, and we see this offer repeated in newsletters for a few years afterwards. This has not been realised to any significant degree: it seems that while a number of activities are now presented at the BRC that can be described as tangentially Buddhist (eg ecology, T'ai Chi, art), it has been found easier to bring in the other organisation's personnel as teachers and present the resulting activity as a BRC retreat.

Gavin Harrison took Osler's place as resident teacher in the second half of 1981. Harrison would later become better known as the author of "In the lap of the Buddha," which recounts his spiritual struggle in the face of his HIV-positive status.

\footnotetext{
${ }^{8} \mathrm{BRC}(1980)$

${ }^{9}$ That is, the full moon in April/May.

${ }^{10}$ Interview: Antony Osler.
} 
The 1981 newsletter shows that the BRC was starting to adapt to the South African spiritual "market." Retreat topics started to branch out: "Judaeo-Christian-Buddhist dialogue"; "The world of bonzai"; and the first "Basic Buddhism."11

Joseph Goldstein, one of the founders of the Insight Meditation Society in Barre, Massachussets, one of the oldest Western retreat centres, ${ }^{12}$ was the first visiting teacher in January 1981. Daily rates for his retreat surged from the normal R10-R24 to R65, to cover his airfare. In 1982 he was followed by Sharon Salzburg, also from IMS. Both were to return in 1983 and have conducted several retreats since. From this point onwards, we see the BRC's focus slowly shifting from its initial concentration on Zen to the westernised form of Theravada developed at IMS. But this did not mean that other forms of Buddhism were completely abandoned: Since those early days, the centre has hosted visiting teachers from various Zen and Tibetan lineages. However, the focus has remained on meditation - ritualistic expressions of Buddhism have by and large not been among the BRC's offerings.

At the end of the 1981 newsletter there is a small notice about a local Buddhist group starting in Pretoria. This marks the beginning of a loose network of meditation groups in the major cities (and a few of the larger towns) that now spans the entire country and has, at times, extended into neighbouring countries. The degree to which these groups are affiliated either to the BRC or to the Buddhist Institute of South Africa varies. South African Buddhism greatly tends towards atomism and local independence, and even those groups that self-identify themselves as formal "affiliates" of the BRC are largely managed at local level.

1982 saw the first Theravada visiting teachers, Ven Piyadassi ${ }^{13}$ and Ayya Khema. ${ }^{14}$ Retreat topics continue to diverge. By now only a single 5-day sesshin was scheduled for the second half of 1982, although two 9-day "Intensive retreats" can probably be seen in the same light. But other topics such as "Ikebana" and "Buddhism and science" start to make their appearance. 1982 also saw the first bird-watching retreat, which has since become one of the BRC's mainstays. ${ }^{15}$

In 1983, the pattern of the previous year continues. The BRC also branched out beyond the strictly-defined boundaries of Buddhism when it offered retreats on Hinduism ("Yoga and Classical Indian dance") and Chinese religion ("Taoism and T'ai Chi"). ${ }^{16}$

Antony Osler left the BRC in late 1983 to take up monastic life at the Mount Baldy Zen Center in the USA. ${ }^{17}$ Upon his return to South Africa in 1988, he settled in Colesberg where he combined legal practice with the creation of a small Zen-oriented retreat centre on his farm in that area. From time to time, he also still

\footnotetext{
${ }^{11} \mathrm{BRC}(1981)$.

${ }^{12} \mathrm{IMS}$, as it is widely known, has been in operation since 1976 .

${ }^{13}$ See Fairall (1982), Harris (1982).

${ }^{14}$ See Staniland (1982).

${ }^{15} \mathrm{BRC}(1982)$.

${ }^{16} \mathrm{BRC}(1983 \mathrm{a})$

${ }^{17} \mathrm{BRC}(1983 b)$ and interview.
} 
leads retreats at the $\mathrm{BRC}$. For the next ten years, then, the BRC would be without an official full-time teacher and Louis van Loon found himself increasingly drawn into a teaching role. This role continues today, even with other teachers now available.

1984 saw the introduction of art retreats; "Sumi-e - the way of the brush," and "Seeing-drawing", two topics that have proved to be yet two more hardy perennials in the BRC's repertoire. More birdwatching retreats were alternated with retreats of a more traditional Buddhist nature, led by visiting teachers such as Namgyal Rimpoche, Ayya Khema and Bhikkhu Anando. ${ }^{18}$ Towards the end of this year, Anando urged Louis van Loon to start building the Buddha statue. In fact, he extended his stay at the centre to do so. The statue they built together (with some help from retreatants) is regarded as the largest hand-built Buddha statue in the Western world. There are other, larger statues elsewhere, but as far as can be ascertained these have all been imported from Asia in semi-finished form and merely assembled on site.

This year also saw the first appearance of the Sri Lankan lay teacher Godwin Samararatne. Although he initially came in as a last-minute replacement for another teacher, Samararatne developed an immediate rapport with the South African Buddhist community. The experience also launched him onto the international Buddhist teachers' circuit and from South Africa he went on to teach at centres in Europe and the USA. He was to return to South Africa regularly over the next fifteen years, annually at first and then on a roughly biannual basis until his death in $2000 .^{19}$ During this period, which saw an increasing fragmentation of South African Buddhism, "Godwin," as he was universally known, was the one teacher universally welcomed by Theravada, Zen and Tibetan groups. On each visit he would teach at these groups as well as at the BRC. With the Tibetan Buddhist establishment, special permission had to be sought from overseas for him to teach at their centres. A new meditation centre currently being constructed in the Magaliesberg area intends to commemorate Godwin by naming its main meditation hall after him. It would hardly be an exaggeration to think of him, with Van Loon and a few others, as one of the founders of South African Buddhism.

The December 1984 newsletter also announces a retreat by Louis van Loon in Somerset West. Although this was not something that would often be repeated in the future, the fact that Louis van Loon was by now in demand as a teacher in other groups and centres suggests a growing self-acceptance on his part of his role as one of the main voices of Buddhism in South Africa. It is a role that persists to this day: he has been the mainstay in the presentations of retreats at the BRC, especially in the difficult period from 1984 to 1994, when the centre was essentially without a permanent teacher. He has also been consulted during the constitutional talks leading up to the 1994 elections, where he essentially served as the public face and voice of South African Buddhism.

The February-August 1989 newsletter shows an interesting entry: the BRC secretary asks people to confirm bookings made by telephone, "as many of our retreats are fully booked these days [and] we often have to put people on waiting lists for these retreats". ${ }^{20}$ The fact that overbooking and waiting lists were now

\footnotetext{
${ }^{18} \mathrm{BRC}(1984)$.

${ }^{19}$ eg $\operatorname{BRC}(1987,1988,1991 \mathrm{a})$.

${ }^{20} \mathrm{BRC}(1989 \mathrm{a}: 3)$.
} 
becoming a problem shows that the Centre was by then not merely viable, but a vital factor in the life of the South African Buddhist community it had helped to create. Naturally, not everything would be smooth sailing from here on. There would be financial problems ${ }^{21}$, personality clashes and various other crises to overcome. But the general pattern had been established and would continue: today not "many" but virtually all BRC retreats are fully booked well in advance.

By 1991, Mervyn Croft, who had already been on the Centre's full-time staff since 1986 and had informally been assisting Louis van Loon and other teachers in giving retreats, started to lead retreats under his own name. ${ }^{22}$ Other local teachers who have been active at the BRC in a teaching capacity include Rob Nairn and Heila Downey. Today they are leading figures in, respectively, the Tibetan Buddhist and Zen establishments in the country. Foreign teachers, apart from those already mentioned, have included Steve Allen, Ven Olande Ananda Thera, Zen master Seung Sahn, Douglas Harding and many others. The BRC's emphasis on interreligious dialogue and practice has also made it possible for non-Buddhist spiritual leaders to conduct retreats there; among these has been the Catholic mystic Father Sepp Anthofer.

Louis and Molly van Loon were divorced in 1987. Louis van Loon married Chrisi McGrath in 1989 and has continued to live in Durban and to play a pivotal role in the running of the BRC. ${ }^{23}$ Chrisi van Loon herself has come to play an active role as well. Although Molly van Loon was still elected to the executive committee of the Buddhist Institute of South Africa (see below) for 1989, she moved to Johannesburg soon afterwards and cut all ties with the BRC and the Institute. She died in 2000, her will stipulating that no piece in her collection of Buddhist art should be allowed to fall into the hands of either Louis van Loon or the Buddhist Institute of South Africa.

In 1995 the BRC gained two western-born ex-monastics as permanent teachers. Now married to each other, they have continued to be known by their former monastic names of Kittisaro and Thanissara. ${ }^{24}$ We find the first mention of their impending arrival in the May-December 1994 brochure. ${ }^{25}$ At first, their intention was to spend half their teaching time in South Africa and half elsewhere, but in fact their increasing popularity has led to them now spending around nine months of the year here and three months overseas, mostly in the United Kingdom. They continue to teach intermittently at the BRC, but have also founded a small Buddhist establishment of their own, called Dharmagiri, near Underberg. Relations between the two centres are cordial and they seem to have worked out different roles for themselves that prevent competition between them. This arrangement fits into the broader role of the BRC within the South African Buddhist community, which will be discussed below.

\footnotetext{
${ }^{21}$ eg BRC (1996:8-9).

${ }^{22} \mathrm{BRC}(1991 \mathrm{~b})$.

${ }^{23} \mathrm{BRC}(1989 b)$.

${ }^{24}$ or sometimes, amongst retreatants, just as "K \& T".

${ }^{25} \mathrm{BRC}(1994)$.
} 
By 1999, some long-time resident staff members left the centre. Perhaps coincidentally, this period also saw a change in the design of the newsletters ${ }^{26}$ Not only was there now a single large folding page instead of the previous saddle-stitched booklet-style publication, but the 2-3 page essays on Buddhism and the day-to-day running of the Centre vanished. When more general news and reflections have been published since then, this has generally been done on separate loose-leaf inserts rather than in the main body of the newsletter.

One may speculate that this change was not merely the result of cost constraints: after nearly twenty years, perhaps both Buddhism and the centre generally were sufficiently well-established in South Africa that it was no longer felt to be necessary to use the newsletter as an introduction to Buddhist thought. From this point onwards, the newsletter becomes more "business-like"; its authors assume that its readership is well established and is primarily interested in retreat details.

\section{Practice and relations}

The BRC's primary, indeed almost exclusive, activity is the organisation and presentation of "retreats." So successful has it been at this task that the South African Buddhist community now uses the term "retreat" for even the shortest gathering and seems incapable of conceptualising other possible means of pursuing communal Buddhist practice.

Since about 1985, then, the BRC seemed to have found its niche. Retreat topics from that year onward have remained on its programme and are still regularly presented. This is not to say that it has become moribund: new topics for retreats have explored, for example, the relations between Buddhist thought and Existentialist philosophy, and special men's, women's and children's retreats have become a regular addition to the programme. But the blend of topics presented at the centre, the kind of retreats it is willing to present, has not changed drastically over the last twenty years.

Indeed, the relative lack of change in retreat contents at the BRC over the last twenty years is theoretically problematic. The spread of Buddhism in the Western World has received much attention from Buddhological theorists recently. Prominent among these have been the work of Michael Pye and Martin Baumann, and also my own work on the subject, which has largely been based on theirs. ${ }^{27} \mathrm{~A}$ common thread in these theories is the assertion that after an initial period in which Buddhism is presented to the "target society" in a way that borrows heavily from that society's conceptual framework, there will be a later stage in which there is a return to the "pure", "unadulterated" Buddhism as it is practised in the country of origin. Theories and theorists disagree about the exact nature and timing of this recoupment process, but mostly they agree that it is a necessary stage in the development of Buddhism in a new social environment. Without it, it is hard to see how there can be any development of an indigenous Buddhist tradition.

But the BRC seems to be stuck in the initial stage, in which Buddhist ideas are presented to the new, non-Buddhist environment in an attractive form that seeks to draw parallels with the receiving culture rather than emphasise the distinctiveness of Asian Buddhism. In the BRC's case, we can see this in the proportion of retreats

\footnotetext{
${ }^{26} \mathrm{BRC}$ (1999).

${ }^{27}$ See Pye (1969), Baumann (1994), Clasquin (1999).
} 
that seem specifically Buddhist versus those concerned with non-Buddhist, or even non-religious, aspects of life. A quick glance at the June 2003-January 2004 newsletter gives us the following list of formal conducted retreats: ${ }^{28}$

The BRC goes juvenile: A retreat for children and their parents

Nurturing your creativity

The way of effortless effort: Tai Ch'i

Sketch from scratch: Can't draw a straight line?

Trading until the end of business: Releasing the beloved

Breathing life into Ch'i Kung

A guide to joyful living: A course in basic Buddhism and meditation

"Hell is other people: Exploring relationships

Zen Pen: A writing/meditation retreat

Good heavens! Come fly a kite

Mindfulness: The ultimate cure

SO S: Awakening to self, other and spirit:, a retreat for women

Drumming up stillness: A drumming retreat

Healing into awareness: Buddhism and psychotherapy

Making friends with adversity: Otherwise, we'll always be angry ...

That's it! A Zen retreat

A Tai Ch'i workshop: Meditation in movement

Yogis live longer: A Hatha Yoga workshop

Finding relief in clay

Paint your dreams

Embodied spirituality: Wholeness through yoga and meditation

Basho's pond: A silent retreat for frogs

Ageless living, fearless ageing

100 Birds of a feather: Bird watching at the BRC

Grounded like a tree open to the sky: An introduction to Ch'i Kung

The way of the mystic: Meditations from the heart

Awakening the enlightened heart: Transformation through meditation

Silent night, dharma night: Christmas at the BRC

An insight and Zen retreat

Personal meditation and study

A dharma study retreat

From a purist perspective one could ask, what happened to the "Buddhist" in the Buddhist Retreat centre? Hatha yoga comes from the Hindu tradition, Tai Ch'i from Taoism. Bird-watching, painting, kite-flying; are these intrinsically Buddhist activities? Has the BRC abandoned its Buddhist roots and become a New Age centre where everything goes? It must be admitted that there are those in the South African Buddhist community who have voiced such opinions from time to time. They acknowledge that the BRC is responding to the needs of the South African public, and they appreciate the special circumstances under which it operates, but they wonder if the pendulum has not swung too far away from a traditional understanding of Buddhism.

${ }^{28} \mathrm{BRC}$ (2003). "Self-retreats" and "work retreats" are also available. 
But to adopt that perspective is to ignore the special role that the BRC has created for itself. In Buddhist circles, it is often referred to in an affectionate way as "the kindergarten," a term that Van Loon first coined himself. Back in 1980, when it was nearly the only Buddhist establishment in South Africa, and certainly the only one run on a fulltime basis, such a criticism might have been valid. But twenty-five years later, there is a Zen centre in Robertson, a Tibetan gompa in Johannesburg, not to mention local Buddhist groups from various traditions in every major city and a few of the larger towns. There is now ample opportunity in South Africa for those who wish to undertake strict, traditional practice of one form or another. Even within Kwazulu-Natal, the Dharmagiri centre near Underberg serves such a function - it presents no weekend retreats, only those lasting two weeks and longer, and membership is restricted, indeed one gets in there almost by invitation only. Indeed, with Kittisaro and Thanissara now spending a larger amount of time at Dharmagiri, it could once again be said that the BRC is without a fulltime permanent teacher. To give another pertinent example, the Nan Hua Temple near Bronkhorstspruit presents Buddhism in a strictly traditional Chinese way, but it could be asked whether such an approach would meet with any success if the ground had not been prepared, and contiues to be prepared, by institutions such as the BRC.

Thus we see that in terms of South African Buddhism as a whole, there is indeed a "recoupment" process taking place - but it is mainly happening elsewhere. While that is going on, there remains a need for a facility where the initial stage of introducing Buddhist ideas to society can continue, and this is the role that the BRC has taken on. Buddhological theories of Buddhist expansion turn out to be not exactly invalidated by the case of the BRC, but in need of further refinement: Just because one process started earlier than another does not imply that it is superseded and effectively stopped by the second process ${ }^{29}$ : It continues in its own right and continues to influence the later processes. Antony Osler expressed the creative tension between these activities as follows:

I think Louis in particular felt that we needed to cater to people who were just ordinary South Africans who wanted access to this sort of thing, but we also understood that we needed some kind of stronger commitment, a base of people who weren't just drifting in and out, but who had made a lifestyle choice ... . [the arrival of Kittisaro and Thanissara was] an outflow of that part of the BRC. I think that issue has still never quite been settled, there is a sense that somewhere in South Africa there should be a group of dedicated people in an almost monastic setting, and that this should be the source of your teachers . . . This has never quite been settled, but perhaps that has just been accepted as the way it is. ${ }^{30}$

The BRC serves as a gateway, a place where people who are just vaguely interested in Buddhism can be introduced to it in a gentle way through birdwatching, kite-flying and so on. Some will eventually move on to more specific forms of Buddhist practice, others will continue to regard the BRC as the spiritual home that is right for them. Indeed, many members and leading figures of more traditionalist

\footnotetext{
${ }^{29} \mathrm{cf}$ Clasquin (1999:37).

${ }^{30}$ Interview: Antony Osler.
} 
groups recognise the $\mathrm{BRC}$ as the place where their spiritual journey began. For example, soon after Zen teacher Stephen Allen visited the BRC in 1986, a Zen group was founded in Johannesburg. Later, a visit by Zen master Seung Sahn proved immensely influential in determining the future development of Zen in South Africa. In yet another instance, the genesis of the Gelugpa lineage in South Africa can be traced directly to Geshe Damcho's visits to the BRC back in the 1980's. Occasionally, the leading figures of these distant offshoots have returned to lead occasional retreats at the BRC. Sometimes this has worked well, at other times, " . . . people have come back, given retreats, but the community didn't respond well to them." 31

Nor is the BRC much perturbed by the incorporation of practices from other religious traditions - it can be seen as a continuation of the interreligious dialogue that was part of its mission from the outset. Perhaps these days there is less urgency about dialogueing with Christians and more interest in trying out techniques from Hinduism and Taoism; but that might change again in the future, and in fact some Catholic nuns from a nearby convent are among the regular retreatants. The BRC, under Van Loon's direction, does not wish to turn Buddhism into yet another hard, unmalleable "ism."

Moreover, a superficial reading of the BRC brochure can be misleading. On first glance, for example, it seems that in 1983, the BRC saw itself as an institution of higher learning. Besides the series of retreats on "Buddhism and science," 1983 also saw a "Wesak Buddhist Studies course" in which Louis van Loon was assisted by Patrick Maxwell, of the Religious Studies department at the University of Natal. ${ }^{32}$ The later 1980s would also see the presentation of Abhidhamma retreats. These more studious-sounding retreat titles are now rare at the BRC. When I put the question to van Loon, his reply was twofold: Firstly,

We did in the beginning use rather classical descriptions for our retreats. We had vipassana retreats, for instance, and abhidhamma retreats. And quite clearly, you can only do that sort of thing in an environment where people know what you are talking about. In those days, nobody in South Africa knew what 'vipassana' meant, and so it would fall flat. Nobody would turn up. So I had to throttle back and go back to a much earlier stage of one's development of interest in Buddhism. So let's rather call it 'Basic Buddhism'. ${ }^{33}$

Secondly, it should be noted that even during birdwatching or kite-flying retreats there are regular meditation sessions every day, with instructions if required. Rather than taking a pedantic "let's talk about Buddhism" approach, these retreats gently bring the non-Buddhist world into a Buddhist context. Newcomers are allowed to ease into the Buddhist lifestyle rather than being asked to make a clean break with their familiar worldview.

\section{Environmental and social activities}

\footnotetext{
${ }^{31}$ ibid.

${ }^{32} \mathrm{BRC}(1983 a, 1983 b)$.

${ }^{33}$ Interview: L van Loon
} 
Ecological concern has long been a prime concern of the BRC staff, and when bird-watching retreats started to take off, this aspect really started to come to the fore. The dam area was the first to be planted with indigenous trees, and weekend retreats were organised to hack away bugweeds and wattle seedlings. Mervyn Croft was particularly involved in these efforts, and the foundation he laid during his years at the centre has continued to prosper. The BRC has been awarded National Heritage Site status, especially for its work in the conservation of the highly endangered blue swallow - the centre having since 1986 been a regular nesting site for two out of only thirty or so known breeding pairs. Other species have thrived as well: when the number of species of birds on the property was first recorded, only 48 were found. Today, 165 species are routinely sighted. Small mammal species can also be found on the centre grounds.

In 1996, a long-negotiated land swop with paper company SAPPI went into effect and the BRC attained a long-cherished goal of consolidating its holdings up to the nearest road. ${ }^{34}$ These areas remain covered with wattle plantations. In fact, even though at its peak, the centre was one of the elite plantations that could produce twenty tons of wattle bark per hectare and the plantation created a positive cash flow during the early years, the wattle operations has turned out not to be the major source of income that had initially been hoped for. It is kept going mainly because it provides employment to about twenty Zulu people in the area, some fulltime, others on a seasonal basis.

Social upliftment has also featured largely among the BRC's activities. At first this was largely restricted to the immediate area and performed largely on the individual initiative of staff members. In the early 80's for example, the centre helped the local Zulu community to build a school. More recently, the Woza Moya project has been a joint effort between the BRC and the Dharmagiri centre to help disadvantaged communities throughout Kwazulu-Natal Province. A BRC staff member is now working full-time on this project. The next step is to raise funds to build an office for the project on the BRC's doorstep.

The ideal is for the disadvantaged community to take over the project eventually, with the BRC taking more of a supervisory role. As van Loon put it, "We want the project to be theirs, not our little white do-gooder sort of thing." ${ }^{35}$ To appreciate the significance of this statement, we need to look at the BRC's clientele and its relations to the people who live nearby.

It must be admitted that the BRC, like most South African Buddhist organisations, has yet to draw significant support from outside its traditional white, middle-class following. "When I go out there, all the cars are like mine, only a lot newer; everybody comes from a similar background, and I do think that is a pity; it isn't necessarily wrong, but it is a limitation." ${ }^{16}$ It is a problem that is not unique to the BRC nor even to South African Buddhism, and I have written about it elsewhere. ${ }^{37}$ However, the rural setting of the BRC throws the dilemma into sharp relief: the divide is not only white vs black, and middle vs working class, but also urban vs rural.

\footnotetext{
${ }^{34} \mathrm{BRC}(1996)$.

${ }^{35}$ Interview: L Van Loon.

${ }^{36}$ Interview: Antony Osler.

${ }^{37}$ See Clasquin (1999, esp ch 6).
} 
That is definitely not to say that the BRC is in any sense a racist organisation. In fact, it threw its doors open to all races from the very beginning, a time in South Africa's history when it could be dangerous to do so - and was visited by government agents for its pains. ${ }^{38}$ The problem is rather that few non-white, non-middle class, non-urban people have felt the need to go through those doors. As a black middle class develops, the BRC is only now starting to see the first beginnings of black interest in Buddhism and black attendance at retreats. But it is early days yet. For some time to come the BRC will be living with the typically South African situation where "The blacks are still the servants, while the whites are called staff." ${ }^{39}$ Again, it must be stressed that no staff position at the centre has ever been restricted to whites; it is rather the case that no black has ever applied. In a sense, this is understandable: to take a "gap year" at a retreat centre is an action that presupposes a comfortable middle-class existence into which one can easily fall back. Even among South African white Buddhists there is less of a tendency to take out major periods for self-development than among their overseas counterparts: "There is no safety net, so one can't easily say, 'I'll just take a year off'." ${ }^{40}$ One can only speculate how much more this would apply to black South Africans. It is just not something that is easily done by people whose memory of poverty and repression is only one or two generations old. ${ }^{41}$

The result of this is that the BRC's social upliftment activity, like so much charitable work in South Africa, always runs the risk of appearing as noblesse oblige. However good the relations between individual staff members and the nearby Zulu village are (and there have been many such relations over the years) the centre and the village remain separate entities that remain unintegrated. The BRC's sangha lives in the suburbs of Durban and other major cities, not on the hill across the valley.

It is not necessarily a problem, but it certainly is something that people need to be aware of; it mirrors South African society very clearly. It seems unsettled to me, but then again the whole country is unsettled that way. The more specialised Buddhist centres avoid the problem by having the retreatants do all the work, but that only "solves" the problem in that particular situation. ${ }^{42}$

Seen in this light, one can understand the sense of urgency one encounters when one discusses social involvement with BRC members and associates. It is only by handing off the social development structures and resources as soon as feasible, by withdrawing into the background as soon as one can and letting the recipients continue it as a project of their own, that the centre's efforts at social upliftment will cease to have this problem. In a way, it can be seen as yet another lesson in the Buddhist virtue of non-attachment.

\footnotetext{
${ }^{38}$ As mentioned by Van Loon (1999:42-43).

${ }^{39}$ Interview: Antony Osler.

${ }^{40}$ Interview: Thanissara.

${ }^{41}$ cf Van Loon (1999:41-42).

${ }^{42}$ Interview: Antony Osler.
} 


\section{Management, administration, and governance}

The BRC is run under the auspices of the Buddhist Institute of South Africa (BISA). The Institute's inaugural meeting took place at the home of Louis and Molly van Loon in Durban on 7 May 1980. 21 people were present and another 13 represented by proxy. Some early meetings of the BISA were conducted at the Durban venue of the Theosophical Society. Since then, they have been held at Louis van Loon's home. The Institute's executive committee also meets every two months to exercise oversight over the running of the centre.

Despite what the name might suggest, BISA was never meant to be an umbrella body for all South African Buddhists. Initially, there were plans to establish a Buddhist museum and library, a study program by distance education, a bursary fund and so on. The reality of how time-consuming the running of the BRC turned out to be soon caught up with these plans. Nevertheless, BISA's all-encompassing view of Buddhism, its refusal to adhere to a single tradition, has made it the first organisation to be called upon when a conference needs a Buddhist speaker, for example. Louis van Loon himself has been called upon to represent the Buddhist community in talks between the government and the religious communities of the country. It is in this sense, if not in the sense of being directly elected, that BISA can be seen as the most representative Buddhist body in South Africa.

Generally, we are friendly with every single Buddhist group in the country, even when they can't stand each other. We are just so easygoing, and they are all welcome to come and teach. But there's no real chance of uniting all the Buddhists in South Africa. ${ }^{43}$

At the time of writing, Louis van Loon retains ownership of the land on which the BRC is situated. Upon his death, ownership will pass to the Buddhist Trust of South Africa. The trustees of this body do not overlap with either the executive committee of the Buddhist Institute of South Africa, nor with the BRC staff who are responsible for the day-to-day running of the centre. At that stage, the Trust's primary responsibility will be to ensure that Van Loon's legacy is maintained and that the BRC is never transformed into an exclusivist organisation that promotes one kind of Buddhism over others. In such an event, the Trust could, in fact, order the Institute and the centre off its property and start the entire process anew.

It is a complicated structure, and not one that has been precisely duplicated by other centres in the country. But it has allowed the BISA to exist without membership lists, fees or any other bureaucratic machinery. In fact, there is a standing open invitation to all interested parties to attend every BISA annual general meeting and from the outset, this invitation has been printed in the BRC newsletter with the announcement of each BISA AGM. Since the BRC cleans up its mailing lists infrequently, in effect this means that anyone who has ever given the slightest indication of being interested in Buddhism is entitled, indeed invited, to attend the BISA AGM, to table motions and to stand for office.

Under normal circumstances, this might open the possibility of a takeover of BISA by special interest groups or even hostile forces. But the existence of the Trust

\footnotetext{
${ }^{43}$ Interview: L Van Loon.
} 
allows BISA to have this fragile nature. If the Trust did not exist, one would expect the Institute to need far more of the usual trappings of non-profit and religious institutions - a highly detailed constitution, a vision and mission statement, formal membership rolls and so on.

In a way, the administration and governance of the BRC mirrors aspects of Buddhism itself. In one sense, Buddhism is hyper-democratic: All beings can attain enlightenment, none are favoured above others, at least not in the long run. But on another level, Buddhism can be seen as severely autocratic: the guru's word is law. It is by finding a constantly shifting level (dare we call it a Middle Way?) between these extremes that Buddhism persists and develops. In an analogous way, the "autocratic" nature of, currently, Van Loon's ownership of the property, and later, that of the Trust, allows the Institute to conduct its business in a "hyper-democratic" way.

\section{Evaluation and prospects}

In many ways, the BRC has become not only the source from which most other Buddhist establishments have sprung, but also the yardstick against which they measure themselves. Even when other centres decide to do things differently, it is common to hear the BRC used as a reference point to explain the decision. A Buddhist centre may, for example, choose not to emulate the BRC's policy of having meals prepared by a dedicated kitchen staff, but to have retreatants do this themselves. But then the reasoning given for that decision will often contain a line like "We can't afford that right now; we are not well established like Ixopo."

It is common enough for a religious institution to experience a crisis on the death of its charismatic founder. While Louis van Loon remains in good health (and would probably object to the label "charismatic"), the fact remains that one day the BRC will have to continue on its way without his inputs, which remain considerable both managerially and in terms of conducting retreats. When the time comes, will there be enough momentum and a steady stream of volunteers to keep the centre going? Will its role change as the South African Buddhist community matures? For how long will the country need a Buddhist "kindergarten"? We can only speculate. One can only hope that towards the year 2029, there will still be a Buddhist Retreat Centre near the town of Ixopo and that someone will feel called upon to investigate its 50 -year history.

But if the future looks uncertain, one may nevertheless celebrate the past and present. To conclude, then, I offer these remarks by three interviewees, all of whom have had long and fruitful associations with the BRC:

(Thanissara) It is a doorway for people to come to the practice of meditation, even beyond learning that it is a Buddhist thing, but just to get a sense of one's inner life. And it is presented in a way that doesn't make it intimidating or exclusive. It serves that function phenomenally well. Beyond that, it introduces people to diverse expressions of Buddhism. ... I think by now it is a step up from a kindergarten, but perhaps it is a nursery...

(Antony Osler) There was very little Buddhism in this country before the BRC, so in terms of popularising I would say that the number of people who have been through the "kindergarten" must be quite high. Certainly, some people wanted to practice more intensely and 
eventually they all left the centre. For those people, the BRC was never the answer. The monastic core we hoped for was never set up, but it may be that the two goals are not really compatible. ... It is there for a taste, I think, and a break for people whose lives are particularly full and who want to refresh their lives. And for that, it is great.

(Mervyn Croft) It was the pioneering centre and it still is the biggest, most established and most respected centre in South Africa. Also the fact that it brings in teachers from many traditions, and all the spinoffs that have come from that. And I hope that as other centres take root, that we retain that spirit of openness, that we don't get locked up in little enclaves of Zen or Tibetan Buddhism or whatever. The BRC could play a role in that.

\section{References Cited}

Baumann, M. 1994. The transplantation of Buddhism into Germany: Processive modes and strategies of adaptation. Method and Theory in the Study of Religion. 6, 1, pp. 35-61.

Clasquin, M. 1999. Transplanting Buddhism. An investigation into the spread of Buddhism, with special reference to Buddhism in South Africa. D Litt et Phil thesis: University of South Africa.

Fairall, M. 1980. South Africa's first Buddhist retreat. Sunday Tribune, June 221980.

Fairall, M. 1982. The monk who spreads inner peace. Sunday Tribune, May 231982.

Harris, T. 1982. Buddhist monk 'a working vagabond'. The Leader. 42, 18, 7 May 1982.

Horning, G. 1980. Feeding the soul. Natal Mercury, Town and Around Supplement, October 10 1980. p. 8.

Natal Witness Reporter 1980. Buddhist centre is first of its kind. Natal Witness, June 171980.

Pye, M. 1969. The transplantation of religions. Numen. Vol 16, pp. 234-239.

Staniland, A. 1982. A 'venerable lady' travels the world. Natal Witness, June 28 1982.

Still, J. 1981. Wholewheat bread on the table, hessian underfoot. Natal Witness, February 111981.

Van Loon, M. 1989. The Molly van Loon collection of Buddhist art. Pretoria: Unisa Art Gallery.

Van Loon, L. 1999. Buddhism in South Africa: its past history, present status and likely future. in Clasquin, M. \& Krüger, J. S. 1999. Buddhism and Africa. Pretoria: Unisa Press, pp 31-43.

\section{Buddhist Retreat Centre newsletters cited}

The BRC newsletters quoted here come from the private collections of Louis van Loon and Mervyn Croft, whose cooperation is gratefully acknowledged. The first two newsletters produced by the BRC covered the schedule for an entire year. Since 1982, BRC newsletters have been produced on a roughly bi-annual schedule, but not a completely regular one, nor has the interval between the production of a newsletter and its eventual dispatch always been the same - sometimes one month, 
sometimes two. Newsletters will, therefore, here be referenced not by the month in which they were edited or sent out (eg January 1990), but by the following months' retreats which they advertise (eg February-June 1990), since this information has formed the bulk of each newsletter and more accurately describes each one's contents. At different times, newsletters were produced by Louis van Loon, Antony Osler, June Atkinson and Mervyn Croft, with inputs from various other BISA and BRC members.

BRC 1980. Newsletter.

BRC 1981. Newsletter.

BRC 1982. -December Newsletter.

BRC 1983a. January- Newsletter.

BRC 1983b. August-December Newsletter.

BRC 1984. -December Newsletter.

BRC 1987. August-December Newsletter.

BRC 1988. April-August Newsletter.

BRC 1989a. February - August Newsletter.

BRC 1989b. August 1989-February 1990 Newsletter.

BRC 1991a. January-August Newsletter.

BRC 1991b. May 1991-January 1992 Newsletter.

BRC 1994. May-December Newsletter.

BRC 1996. August 1996-April 1997 Newsletter.

BRC 1999. June-October Newsletter.

BRC 2003. June 2003-January 2004 Newsletter.

\section{Interviews}

Antony Osler, Bloemfontein, 28 May 2003

Kittisaro \& Thanissara, Underberg, 15 May 2003

Louis Van Loon, Durban, 14 May 2003, 20 May 2003

Mervyn Croft, Mooinooi, 26 May 2003 